\title{
GROWTH OF SPINACH (AMARANTHUS TRICOLOR L.) UNDER VARIOUS APPLICATIONS OF NUTRIENT CONCENTRATIONS IN HYDROPONIC SYSTEM OF NUTRIENT FILM TECHNIQUE
}

\author{
Sindy Sella Rukmi ${ }^{\text {I) }}$ Aiyen $^{2)}$, Abdul Rauf $^{2)}$ \\ 1) Agrotechnology Program, Faculty of Agriculter, University of Tadulako, Palu Email : sindysella@gmail.com, \\ ${ }^{2)}$ Faculty of Agriculter, University of Tadulako, Palu Email : aiyenb@yahoo.com, Email : rauf_ompo@yahoo.com
}

\begin{abstract}
The research aimed to discover the response of the growth of two spinach species on Nutrient Film Technique (NFT) hydroponic system and the concentration of the appropriate AB Mix solution on each species. The research was conducted in January to February 2016, at Green House, Faculty of Agriculture, Tadulako University by using Split Plot Design method. The main plot was red and green spinach, while the subplot was the concentration of $\mathrm{AB}$ Mix nutrient solution, namely $4 \mathrm{ml} / \mathrm{L}$ of water, $5 \mathrm{ml} / \mathrm{L}$ of water, $6 \mathrm{ml} / \mathrm{L}$ of water and $7 \mathrm{ml} / \mathrm{L}$ of water. The research findings reveal that $\mathrm{AB}$ Mix nutrient solution was generally very good to support the growth of spinach on NFT hydroponic. The green spinach had better response rather than the red one. There was no interaction between species and the concentration of nutrient solution. The good concentration of nutrient solution for green spinach is $6 \mathrm{ml} / \mathrm{L}$. It was showed by the better growth of plant height on all age of plant, the more number of leaves, the canopy and the root (wet and dry) were heavier, while on the red spinach, $5 \mathrm{ml} / \mathrm{L}$ of concentration of nutrient solution resulted in the best growth, yet it was not significantly different from other concentration except on the parameter of plant height and the dry weight of plant canopy.
\end{abstract}

Key Words : Nutrient film technique hydroponic, Nutrient solution, Species.

\section{INTRODUCTION}

Hydroponics is a non-media agricultural land system that can be cultivated in various places. Narrow land area, critical soil conditions, uncontrolled pests and diseases, limited amounts of irrigation water, uncertain seasons, and uniform quality can be overcome with this system (Ida, 2014).

One of the most widely used hydroponic forms is the hydroponic NFT or Nutrient Film Technique system. NFT is one of hydroponic system with a method of cultivation where the roots of plants are in a thin layer of water that circulates and contains nutrients in accordance with the needs of plants (Cooper, 1979 in Dermawati, 1996).

In the NFT system, nutrients for plants are highly dependent on the nutrients provided. Nutrient concentrations that are not able to meet the needs of plants in implementing physiological processes can cause the process of inhibition of growth and development, while the concentration of nutrients that are dissolved too thick will cause plant cells undergo plasmolysis, that is the discharge of cell fluids as attracted by the more concentrated nutrient solution (Schwarz,1995 ; Wijayani 2000).

$\mathrm{AB}$ mix is one of the fertilizer that can be used as a nutrient solution of the hydroponics system. This fertilizer consists of two parts namely stock $A$ in the form of macronutrients, while stock $\mathrm{B}$ is a micronutrient. The recommended dosage of $5 \mathrm{ml} / \mathrm{L}$ of water from the producers is for a wide variety of plants, not on certain species such as green vegetables so that proper nutrient concentration is required to 
obtain optimal plant growth in certain species. In this connection, further study was conducted on the proper dose of nutrients for certain spinach types in the NFT hydroponics system. The goal to be achieved was to learn how to grow spinach on the NFT hydroponics system, to study the response of spinach to the concentration of nutrient solutions in the NFT hydroponics system, and determine the best nutrient concentration for each spinach species.

\section{RESEARCH METHODS}

The study was conducted from January to February 2016 at the Greenhouse Faculty of Agriculture, Tadulako University.

The instruments used in this research were paper label, plastic tray, cork, plastic board, oven, analytical scale, spectrophotometer branded "PG Instrument T-90", centrifuge, pipette, test tube, measuring cup, documentation and stationery. The materials used were pure water (Aquades), sand, red and green spinach seeds (produced by CV.Aditya Sentana Agro), alcohol, and ready-mixed nutrient solution under the trademark of $\mathrm{AB}$ Mix (produced by CV Sapto Bumi Hidroponik).

This study used a split-plot design method in a complete random form repeated 4 times. The main plot was a type of spinach consisting of 2 treatments namely, $\mathrm{S}_{1}$ : Green Spinach and $\mathrm{S}_{2}$ : Red Spinach. The subplot was the concentration of nutrient solution of $\mathrm{AB}$ Mix with 4 concentration level, $\mathrm{K}_{1}: 4 \mathrm{ml} / \mathrm{L}, \mathrm{K}_{2}: 5 \mathrm{ml} / \mathrm{L}$, $\mathrm{K}_{3}: 6 \mathrm{ml} / \mathrm{L}$ and $\mathrm{K}_{4}: 7 \mathrm{ml} / \mathrm{L}$.

Research implementation activities were as follows :

\section{Seedling}

Seeds of green and red spinach were added to the sand medium and kept until 2 weeks old.

2. Preparation of Growing Media

Growing media in the form of rectangular plastic containers with the length of $28 \mathrm{~cm} \mathrm{x}$ width $21 \mathrm{~cm} \times$ height $4 \mathrm{~cm}$. The container was then given a cover made of plastic board. The board was perforated as many as 4 holes with $2.5 \mathrm{~cm}$ diameter functioned as a planting hole. Each container was then filled with $500 \mathrm{ml}$ nutrient solution.

3. Planting

Planting was performed after the seeds were 2 weeks old when the plant had grown two or three leaves (uniform). The root of the plant was coated with cork to support the stem of the plant. Each planting hole planted 3 seeds which then nullified until 1 spinach plant.

4. Preparation of nutrient solutions

The nutrient solution was made from $\mathrm{AB}$ Mix fertilizer. Stock A and B stock were both crystalline powders each dissolved in $500 \mathrm{ml}$ aquades. The concentration used was that the two solutions were combined into:

$\mathrm{K} 1: 4 \mathrm{ml}$ stock $\mathrm{A}+4 \mathrm{ml}$ stock $\mathrm{B}$ then dissolved in 1 liter of aquades

$\mathrm{K} 2$ : $5 \mathrm{ml}$ stock $\mathrm{A}+5 \mathrm{ml}$ stock $\mathrm{B}$ then dissolved in 1 liter of aquades

$\mathrm{K} 3: 6 \mathrm{ml}$ stock $\mathrm{A}+6 \mathrm{ml}$ stock $\mathrm{B}$ then dissolved in 1 liter of aquades

$\mathrm{K} 4: 7 \mathrm{ml}$ stock $\mathrm{A}+7 \mathrm{ml}$ stock $\mathrm{B}$ then dissolved in 1 liter of aquades

5. Application of nutrient solutions

Application of nutrient solution to the plant was performed by the solution filled into the container that has been prepared. Application of nutrient solution in accordance with the concentration tested.

6. Maintenance

Plant maintenance activities include replacing and adding nutrient solution once a week and controlling plant pests.

7. Harvesting

Harvesting was performed after 4 weeks after planting.

\section{Research Variable}

To know the effect of the experiment, then made a number of observations on the growth of plants. The observed as follows:

a. Number of leaves, observed at ages of 14, 21 and 28 DAP. The calculated leaves were perfectly formed leaves. 
b. Plant height $(\mathrm{cm})$, measured uniformly from the surface of the cork.

c. Fresh weight of root and canopy (g), weighed after harvesting with analytic scales.

d. Dry weight of root and canopy (g), the sample was weighed after being put in the oven for 48 hours with temperature of $65^{\circ} \mathrm{C}$.

e. Chlorophyll total $(\mathrm{mg} / \mathrm{g})$, measured by using a spectrophotometer after harvesting. Leaf chlorophyll measurements used the Wintermans and De Mots (1965) method in Banyo et al. (2013), that was $1 \mathrm{~g}$ Fresh leaves that dissolved in $20 \mathrm{ml}$ ethanol (96\%) and measured the absorbance of chlorophyll solution at 649 and $665 \mathrm{~nm}$ wavelengths.

\section{Data Analysis}

The data obtained were analyzed by analysis of variance ( $\mathrm{F}$ test), if the treatment had real effect followed by honestly significant different test (HSD) to know the response of plant type and orthogonal test to know the appropriate concentration on each plant type.

\section{RESULTS AND DISCUSSIONS}

\section{Results}

Plant height. Statistical analysis showed that the concentration of nutrient solution had significant effect on plant height at age of 21 and 28 DAP, whereas the type treatment had significant effect on plant height at age of 14,21 and 28 DAP. The interaction between the concentration of nutrient solution and the type did not have real effect on plant height. At the age of 28 DAP, the nutrient solution of $6 \mathrm{ml} / \mathrm{L}$ resulted in the highest plant height of 35.84 \pm 2.66 and very real difference with treatment of $7 \mathrm{ml} / \mathrm{L}$. Similarly, in red spinach, the response of nutrient solution of $6 \mathrm{ml} / \mathrm{L}$ was significantly different from 4 $\mathrm{ml} / \mathrm{L}$ and very real to $7 \mathrm{ml} / \mathrm{L}$.

In the type treatment, it was shown that green spinach yielded a higher average plant height than red spinach at all plant ages is presented in Table 2. Plant height growth is presented in Table 1.

Table 1. The average of plant height $(\mathrm{cm})$ on $28 \mathrm{DAP}$ at various concentrations of nutrient solution.

\begin{tabular}{|c|c|c|c|c|}
\hline Treatment & \multicolumn{2}{|c|}{ Average } & Treatment & Average \\
\hline S1K1 & \multicolumn{2}{|c|}{$32.08 \pm 1.57$} & S2K1 & $21.78 \pm 4.05$ \\
\hline $\mathrm{S} 1 \mathrm{~K} 2$ & \multicolumn{2}{|c|}{$32.65 \pm 1.32$} & $\mathrm{~S} 2 \mathrm{~K} 2$ & $25.66 \pm 1.17$ \\
\hline S1K3 & \multicolumn{2}{|c|}{$35.84 \pm 2.66$} & $\mathrm{~S} 2 \mathrm{~K} 3$ & $27.53 \pm 1.99$ \\
\hline $\mathrm{S} 1 \mathrm{~K} 4$ & \multicolumn{2}{|c|}{$27.78 \pm 2.30$} & $\mathrm{~S} 2 \mathrm{~K} 4$ & $19.97 \pm 1.45$ \\
\hline \multicolumn{5}{|c|}{ Orthogonal test } \\
\hline \multicolumn{2}{|c|}{ Treatment } & F calculation & Treatment & F calculation \\
\hline \multicolumn{2}{|c|}{ S1K1 Vs S1K2,S1K3,S1K4 } & $0.00 \mathrm{tn}$ & S2K1 Vs S2K2,S2K3,S2K4 & $4.6 *$ \\
\hline \multicolumn{2}{|c|}{ S1K2 Vs S1K3, S1K4 } & $0.43 \mathrm{tn}$ & S2K2 Vs S2K3 Vs S2K4 & $2.2 \mathrm{tn}$ \\
\hline \multicolumn{2}{|c|}{ S1K3 Vs S1K4 } & $29.48 * *$ & $\mathrm{~S} 2 \mathrm{~K} 3 \mathrm{Vs} \mathrm{S} 2 \mathrm{~K} 4$ & $25.9 * *$ \\
\hline \multirow[t]{2}{*}{ F Table } & 0.05 & 4.41 & & 4.41 \\
\hline & 0.01 & 8.29 & & 8.29 \\
\hline
\end{tabular}

Table 2. The average of Plant height $(\mathrm{cm})$ on 14, 21, and 28 DAP of two types of spinach

\begin{tabular}{cccc}
\hline \multirow{2}{*}{ Treatment } & \multicolumn{3}{c}{ Plant height } \\
\cline { 2 - 4 } & 14 DAP & 21 DAP & 28 DAP \\
\hline Green spinach (S1) & $7.58 \mathrm{~b}$ & $14.71 \mathrm{~b}$ & $32.09 \mathrm{~b}$ \\
Red spinach (S2) & $6.08 \mathrm{a}$ & $11.41 \mathrm{a}$ & $23.73 \mathrm{a}$ \\
\hline HSD 5\% & 0.67 & 0.92 & 2.28 \\
\hline
\end{tabular}

Information: The number followed by the same alphabet and column has no significant difference at the HSD level of $5 \%$. 
Table 3. Average number of leaves (helai) on 21 DAP at various concentrations of nutrient solution.

\begin{tabular}{|c|c|c|c|c|}
\hline Treatment & Average & Treatment & \multicolumn{2}{|c|}{ Average } \\
\hline S1K1 & $4.50 \pm 0.64$ & $\mathrm{~S} 2 \mathrm{~K} 1$ & \multicolumn{2}{|c|}{$4.25 \pm 0.57$} \\
\hline $\mathrm{S} 1 \mathrm{~K} 2$ & $4.92 \pm 0.17$ & $\mathrm{~S} 2 \mathrm{~K} 2$ & \multicolumn{2}{|c|}{$4.42 \pm 0.42$} \\
\hline S1K3 & $5.67 \pm 0.47$ & S2K3 & \multicolumn{2}{|c|}{$4.33 \pm 0.38$} \\
\hline $\mathrm{S} 1 \mathrm{~K} 4$ & $4.25 \pm 0.17$ & $\mathrm{~S} 2 \mathrm{~K} 4$ & \multicolumn{2}{|c|}{$3.92 \pm 0.17$} \\
\hline \multicolumn{5}{|c|}{ Orthogonal test } \\
\hline Treatment & F calc & Treatment & \multicolumn{2}{|r|}{ F calc } \\
\hline S1K1 Vs S1K2,S1K3,S1K4 & $3.42 \mathrm{tn}$ & $\mathrm{S} 2 \mathrm{~K} 1 \mathrm{Vs} \mathrm{S} 2 \mathrm{~K} 2, \mathrm{~S} 2 \mathrm{~K} 3, \mathrm{~S} 2 \mathrm{~K} 4$ & & $0.0 \mathrm{tn}$ \\
\hline S1K2 Vs S1K3,S1K4 & $0.03 \mathrm{tn}$ & $\mathrm{S} 2 \mathrm{~K} 2 \mathrm{Vs} \mathrm{S} 2 \mathrm{~K} 3, \mathrm{~S} 2 \mathrm{~K} 4$ & & $1.3 \mathrm{tn}$ \\
\hline S1K3 Vs S1K4 & $23.17 * *$ & S2K3 Vs S2K4 & & $2.0 \mathrm{tn}$ \\
\hline \multirow[t]{2}{*}{ F Table } & 4.41 & & 0.05 & 4.41 \\
\hline & 8.29 & & 0.01 & 8.29 \\
\hline
\end{tabular}

Information: $\quad * *$ : Very real $\quad *$ : Real $\quad{ }^{\text {tn }}$ Unreal

Table 4. Average Number of leaves on 14, 21, and 28 DAP of two types of spinach.

\begin{tabular}{cccc}
\hline \multirow{2}{*}{ Treatment } & \multicolumn{3}{c}{ Number of leaves } \\
\cline { 2 - 4 } & 14 DAP & 21 DAP & 28 DAP \\
\hline Green spinach (S1) & 3.31 & $4.83 \mathrm{~b}$ & $10.60 \mathrm{~b}$ \\
Red spinach (S2) & 3.38 & $4.23 \mathrm{a}$ & $9.44 \mathrm{a}$ \\
\hline HSD 5\% & - & 0.34 & 0.87 \\
\hline
\end{tabular}

Information: The number followed by the same alphabet and column has no significant difference at the HSD level of $5 \%$.

Number of leaves. Statistical analysis showed that the treatment of nutrient concentration had significant effect on the number of leaves at age of 21 DAP, while at age of 14 and 28 DAP did not have real effect. In the treatment of the type of effect was real to the number of leaves at age of 21 and 28 DAP. The interaction between the concentration of nutrient solution and the type had no significant effect on the number of leaves.

In Table 3, the type of green spinach that produced the most number of leaves obtained from the treatment of nutrient concentration of $6 \mathrm{ml} / \mathrm{L}$ with the average number of leaves produced was 5.67 leaves but not significantly different with the concentration of $5 \mathrm{ml} / \mathrm{L}$. In the red spinach, the highest number of leaves was generated by the $5 \mathrm{ml} / \mathrm{L}$ concentration of nutrient solution with the average number of leaves produced was 4.42 leaves but not significantly different with the concentration of other nutrient solutions.

Based on Table 4, on 21 and 28 DAP green spinach produced more leaves than red spinach. This suggested that green spinach provide a better response than red spinach.

Weight of Root. The statistical analysis of fresh weight of roots showed that the concentration treatment of nutrient solution, type and interaction between the two treatments did not significantly affect the fresh weight of roots of spinach plants, while the dry weight of roots showed that the type of treatment significantly affected the dry weight of spinach roots but the concentration of nutrient solution and interaction had no significant effect. In the 
fresh weight parameter was obtained the result that green spinach with a concentration of the nutrient solution of $6 \mathrm{ml} / \mathrm{L}$ resulted in fresh weight of root which was heavier. In red spinach, a concentration of $5 \mathrm{ml} / \mathrm{L}$ nutrient solution had heavier fresh weights which are presented in Table 5.

Table 6 showed that root dry weight of green spinach concentrations of 5 and 6 $\mathrm{ml} / \mathrm{L}$ yielded the heaviest dry weight of root, while in dry weight of roots of red spinach was produced by concentration of $5 \mathrm{ml} / \mathrm{L}$. In general, average dry weight of red spinach roots was heavier than green spinach.

Canopy Weight. The statistical analysis showed that the treatment of nutrient concentration and type showed no significant interaction with fresh canopy weight and each treatment did not significantly affect the fresh weight of spinach canopy while the concentration treatment of nutrient and type significantly affected the dry weight of spinach canopy, but the effect of interaction between nutrition and type had no significant effect.

Table 5. Average Weight of Root (g) at various concentrations of nutrient solution and two types of spinach.

\begin{tabular}{ccc}
\hline \multirow{2}{*}{ Concentration } & \multicolumn{2}{c}{ Treatment } \\
\cline { 2 - 3 } & Green Spinach (V1) & Red Spinach (V2) \\
\hline $4 \mathrm{ml} / \mathrm{L}(\mathrm{K} 1)$ & $4.24 \pm 1.36$ & $5.22 \pm 0.74$ \\
$5 \mathrm{ml} / \mathrm{L}(\mathrm{K} 2)$ & $5.45 \pm 0.60$ & $5.55 \pm 0.58$ \\
$6 \mathrm{ml} / \mathrm{L}(\mathrm{K} 3)$ & $5.90 \pm 1.74$ & $5.23 \pm 1.77$ \\
$7 \mathrm{ml} / \mathrm{L}(\mathrm{K} 4)$ & $4.08 \pm 0.76$ & $4.40 \pm 0.85$ \\
\hline Average & 4.9 & 5.1 \\
\hline
\end{tabular}

Table 6. Average Dry Weight of Root (g) at various concentrations of nutrient solution and two types of spinach.

\begin{tabular}{ccc}
\hline \multirow{2}{*}{ Concentration } & \multicolumn{2}{c}{ Treatment } \\
\cline { 2 - 3 } & Green Spinach (V1) & Red Spinach (V2) \\
\hline $4 \mathrm{ml} / \mathrm{L}(\mathrm{K} 1)$ & $0.27 \pm 0.07$ & $0.33 \pm 0.06$ \\
$5 \mathrm{ml} / \mathrm{L}(\mathrm{K} 2)$ & $0.28 \pm 0.04$ & $0.38 \pm 0.02$ \\
$6 \mathrm{ml} / \mathrm{L}(\mathrm{K} 3)$ & $0.28 \pm 0.13$ & $0.37 \pm 0.15$ \\
$7 \mathrm{ml} / \mathrm{L}(\mathrm{K} 4)$ & $0.24 \pm 0.02$ & $0.27 \pm 0.04$ \\
\hline Average & $0.27 \mathrm{a}$ & $0.34 \mathrm{~b}$ \\
\hline HSD 5\% & & 0.06 \\
\hline
\end{tabular}

Information: The number followed by the same alphabet and column has no significant difference at the HSD level of $5 \%$.

Table 7. Average Canopy Fresh Weight (g) of two types of spinach

\begin{tabular}{ccc}
\hline & \multicolumn{2}{c}{ Treatment } \\
\hline Concentration & Green Spinach (V1) & Red Spinach (V2) \\
\hline $4 \mathrm{ml} / \mathrm{L}(\mathrm{K} 1)$ & $9.09 \pm 1.19$ & $9.62 \pm 1.98$ \\
$5 \mathrm{ml} / \mathrm{L}(\mathrm{K} 2)$ & $9.10 \pm 1.50$ & $10.8 \pm 0.44$ \\
$6 \mathrm{ml} / \mathrm{L}(\mathrm{K} 3)$ & $9.95 \pm 1.39$ & $9.69 \pm 1.32$ \\
$7 \mathrm{ml} / \mathrm{L}(\mathrm{K} 4)$ & $8.12 \pm 1.18$ & $9.02 \pm 0.74$ \\
\hline Average & 9.07 & 9.79 \\
\hline
\end{tabular}


Table 8. Average Canopy Fresh Weight at various concentrations of nutrient solution (g).

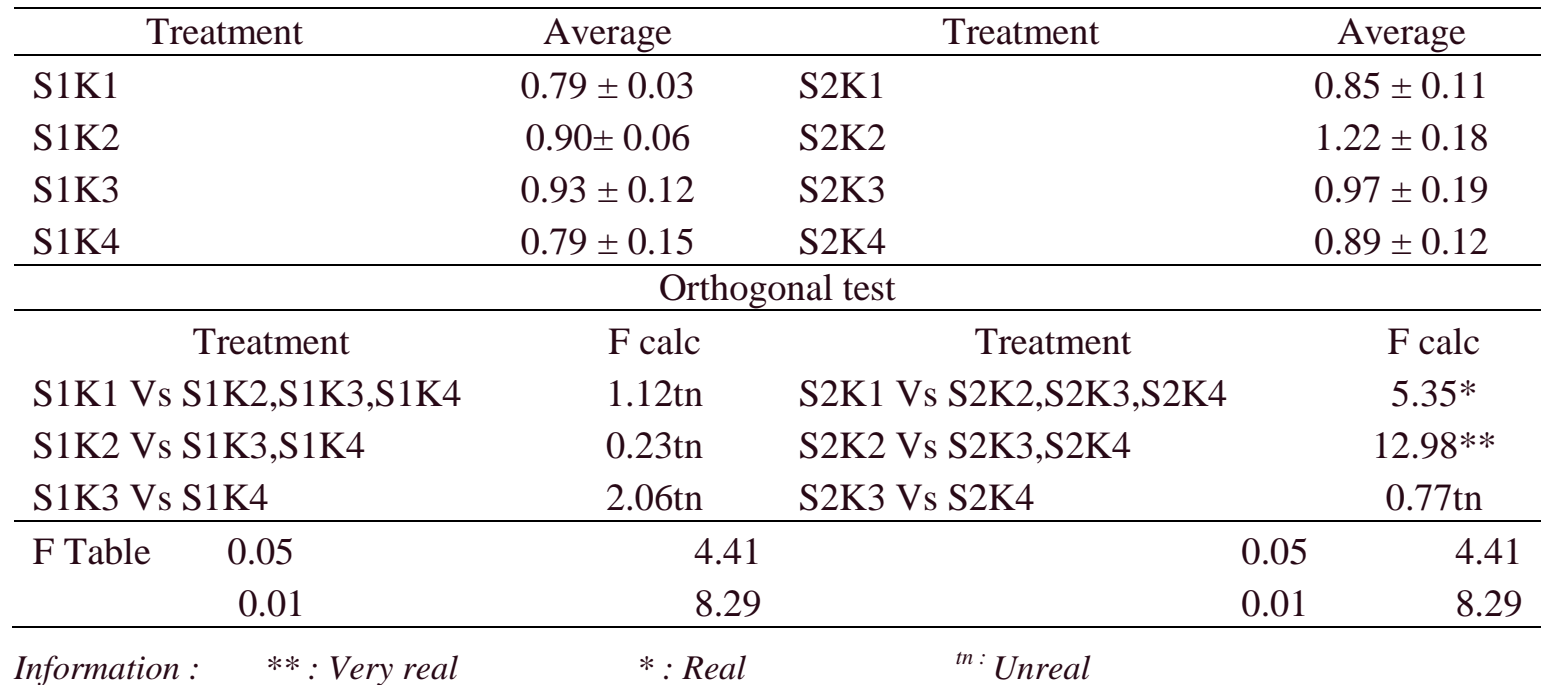

Table 9. Average Canopy Dry Weight (g) of two types of spinach.

\begin{tabular}{|c|c|}
\hline Treatment & Canopy Dry Weight \\
\hline Green spinach (V1) & $0.85 \mathrm{a}$ \\
\hline Red spinach (V2) & $0.99 \mathrm{~b}$ \\
\hline HSD 5\% & 0.122 \\
\hline
\end{tabular}

Table 10. Average Number of Chlorophyll $(\mathrm{mg} / \mathrm{g})$ at various concentrations of nutrient solution and two types of spinach.

\begin{tabular}{lll}
\hline & \multicolumn{2}{c}{ Treatment } \\
\hline Concentration & Green Spinach (V1) & Red Spinach (V2) \\
\hline $4 \mathrm{ml} / \mathrm{L}(\mathrm{K} 1)$ & $0.02 \pm 0.01$ & $0.03 \pm 0.01$ \\
$5 \mathrm{ml} / \mathrm{L}(\mathrm{K} 2)$ & $0.04 \pm 0.01$ & $0.04 \pm 0.01$ \\
$6 \mathrm{ml} / \mathrm{L}(\mathrm{k} 3)$ & $0.05 \pm 0.03$ & $0.03 \pm 0.01$ \\
$7 \mathrm{ml} / \mathrm{L}(\mathrm{K} 4)$ & $0.03 \pm 0.02$ & $0.04 \pm 0.03$ \\
\hline Average & 0.15 & 0.13 \\
\hline
\end{tabular}

Based on table 8 , the type of green spinach which resulted in the heaviest dry weight that was obtained from the treatment of nutrient solution concentration of $6 \mathrm{ml} / \mathrm{L}$ with $0.93 \pm 0.12$ average but not significantly different with other nutrient concentrations whereas in the heaviest dry weight of red spinach canopy was produced by the concentration of $5 \mathrm{ml} / \mathrm{L}$ nutrient solution with average of $1.22 \pm 0.18$.
In this treatment of type, the heaviest canopy dry weight produced by red spinach of $0.99 \mathrm{~g}$ while green spinach yielded only $0.65 \mathrm{~g}$ of dry weight that is presented in Table 9.

Leaf chlorophyll. Statistical analysis showed that the interaction of nutrient concentration and type had no significant effect and each treatment also had no significant effect on the amount of plant 
chlorophyll. The effect of such treatment is presented in Table 10.

\section{Discussions}

The results showed that spinach that grown on hydroponic NFT systems could grow well. The free-selling hydroponic nutrient solution, AB-Mix (goodplant) had a positive effect on the growth of green spinach and red spinach.

Different concentrations of nutrient solution had significant effect on plant height, the number of leaves, dry weight of root and canopy dry weight. In plant height, the number of leaves, dry root and canopy weight, nutrient solution concentration of 6 $\mathrm{ml} / \mathrm{L}$ showed better results on green spinach and $5 \mathrm{ml} / \mathrm{L}$ in red spinach.

From the observation of plant height, number of leaves, dry root weight, and canopy dry weight, in green spinach there was an increase of crop yield along with the increase of nutrient solution concentration from $4 \mathrm{ml} / \mathrm{L}$ to $6 \mathrm{ml} / \mathrm{L}$, but at the concentration of $7 \mathrm{ml} / \mathrm{L}$ the was decrease of crop yields. Thus the concentration of 6 $\mathrm{ml} / \mathrm{L}$ was the optimum concentration in green spinach. In red spinach, there was an increase in crop yield along with the increase of nutrient solution concentration from $4 \mathrm{ml} / \mathrm{L}$ to $5 \mathrm{ml} / \mathrm{L}$ but there is a decrease in yield at the concentration of 6 to $7 \mathrm{ml} / \mathrm{L}$.

According to Schwarz (1995) in Dermawati (2000) and Kristanti (1998), the concentration of nutrients that is unable to meet the needs of plants in implementing physiological processes can cause the inhibitation of growth and development, while the concentration of nutrients dissolved that is too thick, it can make plants less maximum to absorb nutrients contained therein. Such concentrations can affect plant metabolism, namely the speed of photosynthesis, enzyme activity, and the potential absorption of ion of the solution by the roots so as to affect nutrient absorption.

According to Wijayani and Widodo (2005), concentrated solutions cannot be absorbed by the roots maximally, due to the cell osmotic pressure being smaller than the osmotic pressure outside the cell, thus the possibility of a return fluid of plant cells (plasmolysis). This was supported by the research of Moerhasrianto (2011), which found that the growth rate of crops tended to increase with increasing concentration of "Growmore" nutrition to a concentration of $2.5 \mathrm{~g} / \mathrm{l}$, but decreased at higher concentrations of $3 \mathrm{~g} / \mathrm{l}$. The decrease of growth rate is due to nutrient solution which has high nutrient nitrogen content, which according to Runhayat (2007), the use of $\mathrm{N}$ nutrient solution concentration above the optimum point causes plant growth to be inhibited. This result is also consistent with the fact that $\mathrm{N}$ nutrient is toxic to plants when the amount is too much.

The results of this study also showed a significant effect on the treatment of different types on plant height, number of leaves, and canopy dry weight. The type treatment showed green spinach and red spinach had different growth responses to each of the concentrations of nutrient solution. On the dry weight parameter of plant canopy was obtained the result that verage dry weight of canopy on green spinach was $0.93 \mathrm{~g}$, while red spinach was $1.22 \mathrm{~g}$.

According to Sitompul and Guritno (1995), the difference in genetic makeup is one of the factors causing the diversity of plant appearance. Genetic programs in a different growth phase can be expressed on a variety of plant traits that include the shape and function of the plant to produce a growth diversity. The diversity of plant appearance due to differences in genetic makeup is always possible even if the plants used are of the same kind.

\section{CONCLUSIONS AND SUGGESTIONS}

\section{Conclusions}

This study yields several conclusions:

1. AB-Mix nutrient solution can be used to grow red and green spinach with NFT hydroponic system. 
2. The AB-Mix solution with a Suggestions concentration of $6 \mathrm{ml} / \mathrm{L}$ gave the best growth for green spinach and $5 \mathrm{ml} / \mathrm{L}$ for red spinach.

For better results it is advisable to use $\mathrm{AB}$ Mix as much as $5 \mathrm{ml} / \mathrm{L}$ for red spinach and $6 \mathrm{ml} / \mathrm{L}$ for green spinach.

\section{REFERENCES}

Banyo, Y.E., N.S Ai, P.Siahaan, A.M, Tangapo. 2013. Konsentrasi Klorofil Daun Padi pada Saat Kekurangan Air yang Diinduksi dengan Polietilen Glikol. Jurnal Ilmiah Sains Vol. 13 (1):1-8

Candra Ginting dan Teresjia C. Rakian. 2008. Hidroponik: Pertanian Masa Depan Untuk Masyarakat Perkotaan. WARTA-WIPTEK, Volume 16 Nomor 01-01-2008. Universitas Haluoleo. Kendari

Dermawati.2006. Subtitusi Hara Mineral Organik Terhadap Inorganik Terhadap Produksi Tanaman Pakchoi. Skripsi : Fakultas MIPA. Institut Pertanian Bogor. Bogor

Ida Syamsu Roidah.2014. Pemanfaatan Lahan Dengan Menggunakan Sistem Hidroponik. Jurnal Universitas Tulungagung BONOROWO Vol. 1.No.2 Tahun 2014

Kristanti,N. 1998. Karakteristik Konduktivitas Listrik Larutan Nutrisi Tanaman Selada (Lactuva sativa .L) pada System Nutrient Film Technique (NFT) Dengan Sirkulasi Larutan Nutrisi Secara Berkala. Skripsi; Fakultas Pertanian. Institut Pertanian Bogor. Bogor

Moerhasrianto, P. 2011. Respon Pertumbuhan Tiga Macam Sayuran pada Berbagai Konsentrasi Nutrisi Larutan Hidroponik.Skripsi: Jurusan Budidaya Pertanian. Fakultas Pertanian.Universitas Jember.

Runhayat, A. 2007. Penentuan Kebutuhan Pokok Unsur Hara N, P, K Untuk Pertumbuhan Tanaman Panili (Vanilla planifolia). Buletin Littro (Online) http:// balittro.litbang. deptan.go.id/ind/images/stories/Buletin/.../5-panili.pdf. Diakses tanggal 5 Maret 2016.

Sitompul,S.M. dan Guritno.1995. Analisis Pertumbuhan Tanaman. Gadjah Mada University Press. Yogyakarta

Wijayani, A. 2000. Budiaya Paprika Secara Hidroponik: Pengaruhnya terhadap Serapan Nitrogen dalam Buah. Agrivet Vol 4 (2): 60-65.

Wijayani A. dan Widodo, W. 2005. Usaha Meningkatkan Kualitas Beberapa Varietas Tomat dengan Sistem Budidaya Hidroponik. Ilmu Pertanian, Vol 12 (1) : 77-83. 